\title{
Analysis of specialist opinions about the problem of selection in the game of football for children 6-8 years of age
}

\section{Sorin Brîndescu 1}

\begin{abstract}
The general trend worldwide is a pronounced decrease in the age at which sport performance begins. An early debut in the performance sport requires an early specialization and hence special efforts of the athlete, not just physical (the body has the ability to regenerate), but also of a mental nature. In this study I wanted to obtain the experts opinions on the main aspects of selection for the age studied, namely: selection criteria, methods of encouragement, stimulation and improvement, the overall state of the selection phenomenon organized for children of small age. Sports training professionals appreciate that the future belongs to technicians and athletes able to create new patterns, superior to those present, favoring the creation of highly efficient motor structures in order to obtain success in sports.
\end{abstract}

Key words: selection, football, motor criteria, motivation, 6-8 years of age

\section{Rezumat}

Tendinţa generală, pe plan mondial, este scăderea accentuată a vârstei la care se începe practicarea sportului de performanţă. Un debut timpuriu în sportul de performanţă presupune o specializare timpurie şi implicit eforturi deosebite din partea sportivului, nu numai de natură fizică (organismul are capacitatea de a se regenera), ci şi de natură psihică. Am urmărit în studiul de faţă obţinerea opiniilor specialiştilor cu privire la principalele aspecte ale selecţiei la vârsta studiată şi anume: criterii de selecţie, metode de încurajare, stimulare şi îmbunătăţire, stadiul general al fenomenului de selecţie organizată la nivelul copiilor de vârstă şcolară mică. Specialiştii din domeniul antrenamentului sportiv apreciază că viitorul va aparţine tehnicienilor şi sportivilor apţi să creeze noi modele, superioare celor prezente, care favorizează crearea unor structuri motrice deosebit de eficiente pentru obţinerea succesului sportiv.

Cuvinte cheie: selecţie,fotbal, criterii motrice, motivare, 6-8 ani.

\footnotetext{
${ }^{1}$ Lecturer PhD, West University of Timișoara, Faculty of Physical Education and Sports, e-mail: sorin.brindescu@e-uvt.ro Volume $7 \bullet$ Issue $14 \diamond 2015$
} 


\section{Introduction}

The football game progressed permanently and appreciably, because of its spread and of the large number of people who practice this truly "social phenomenon". This is very enlightening and in regard to children in our country, we see a special attraction for this sport, both in their free time, playing, as well as in an organized environment: school competitions or schools specializing in football trainings.

The selection process is an organized and repeated process for an early detection of inborn skills of the child, using a complex system of criteria (medical, biological, psycho-sociological and motor) for his further practice and specialization in a discipline or sporting event. [1]

The procedural nature of selection involves multiple actions with a fixed sequence: clear delineation of areas of activity and their components, followed by combining and integrating components of activity fields into scientific ways that lead to the achievement of action objectives.

The need to approach very seriously some objective criteria in the selection and sporting orientation, criteria widely recognized and checked, comes from the need to place the whole action of selection on some scientific grounds. [2]

Selection, orientation and training of children and adolescents able to practice a performance sport is not a momentary action but an evolutionary process in which operations are carried out continuously, even during the trainings. A momentary operation only reveals the availabilities of the investigated, materialized in his health, general motor behavior and his strong motivation to do sport, the rest evolving from here.

For the selection and orientation process to benefit from opportunities to succeed, it is necessary, on the one hand, for those who select to know what kind of skills are required by this sport, and on the other hand, for those who are selected to have those qualities to a highest level, knowing that some of them can be perfected by training, and others not so much.

\section{The purpose}

For this paper, which is trying to introduce some new ways of approaching educating new motor skills in children selected in the game of football, we consider it is necessary for physical education teachers in schools and football coaches who train these groups of children ready to be selected, to participate actively and creatively, in order not to lose touch with the requirements of modern international football, as well as upgrading the teaching - learning process for each age group.

Knowledge of new aspects of the theory and practice of contemporary football requires a deepening of the general methodology of modern sports training, combined with an active and effective participation of physical education teachers and football coaches in conducting training.

Specifically, the evolution of this sport has a number of guidelines and trends that directly influence the development of the main motor qualities and also of moral-volitional qualities.

In this regard, whenever it comes to qualities related to stable heritable characteristics (longitudinal dimensions of the body, speed, general skills) the coaches requirements should be very high from the beginning; in situations that require qualities related to labile, perfectible hereditary characters (perimeters and body weight, strength and endurance), the initial requirement may be lower. Particular attention should be paid to mental qualities.

The first years of life have an important role in the development of the motivation for playing football and further on in the development of physical, mental and intellectual qualities. When asked about the possibility of delaying recovery in cultivating physiological and functional qualities, domain experts answer that the possibility of full recovery decreases with the length of the delay. However, the selection of young footballers should take into account the stages of child development, and this must be different for every attribute necessary for great performance. [3]

Research performed by experts on psychomotricity showed that its intensive development occurs between 6-10 years, and that between 10-16 years the process continues normally after systematic practice of football. The most favorable period to start speed development and detention exercises would be between 6-8 years. Strength and resistance must be developed between 9-11 years. Regarding exercises as games, it is 
recommended that they start early, aiming at an overall development since they are 3-4 years old. [4]

\section{Method}

In developing this research we considered that consulting specialists (practitioners) is of great relevance in order to clarify issues related to the selection process. In addition to information taken from expert literature, in order to outline an objective and complete image about the real methods to carry on a selection in team games, we used a questionnaire for those who effectively participate in training athletes of children and juniors.

The questionnaire is made of 18 questions ( 1 with a closed answer and 17 with open answers), meant to provide important information in relation to: quality of the sporting selection for the age of 6-8, in schools and sports clubs and private schools in the west. We also sought to obtain the views of experts on key aspects of selection at the age studied, namely: selection criteria, methods to encourage, stimulate and improve, the overall state of the phenomenon of organized selection for children at a school age.

The teachers and coaches who were kind enough to respond to the questionnaire were 100 , all of them having been specialized in football and carrying their professional activities in schools, school clubs and private clubs in Arad, Timis and Bihor.

I will present the graphical representation of the responses recorded from the 17 questions of the questionnaire above, question 18 not having a free choice answer but being strictly related to the name of the club where each respondent play.

\section{Results}

Q1. What do you think is the best age for initial selection in the football game?

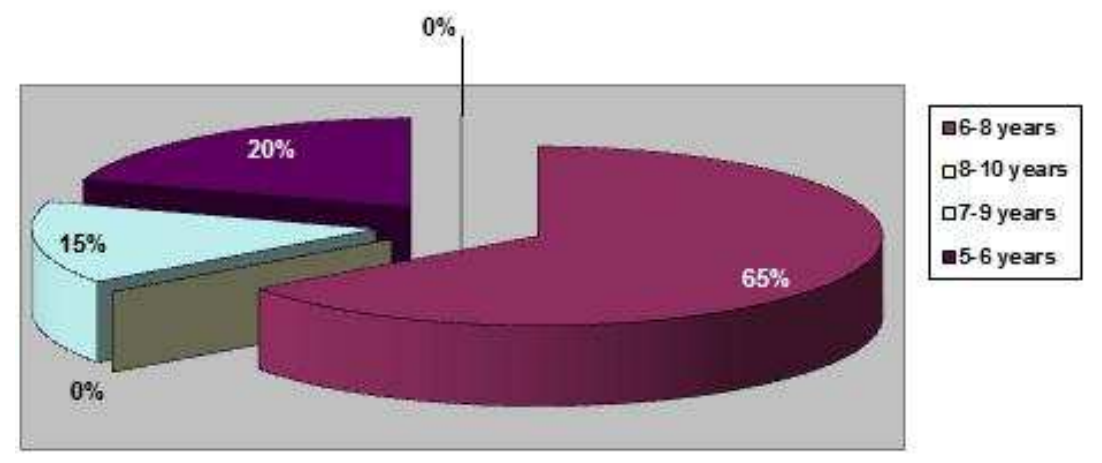

Figure 1. Graphical representation of the responses to question Q1

Regarding the question about the optimal age for initial selection in football, an overwhelming percentage of $65 \%$ believe that it is best achieved between $6-8$, while $15 \%$ believe that between $7-9$ years would be better and $20 \%$ mention 8-10 years. No respondent believes that the initial selection in football game should involve children under the age of 5 .
Q2. Which do you believe are the most effective selection criteria the experts should take into account?

When asked about the effectiveness of criteria for initial selection in football a 50\% mentions the motor ones followed by psychological ones nominated by $25 \%$ of respondents, medicobiological and biochemical ones by $10 \%$ and somato-physiological ones by $5 \%$. 


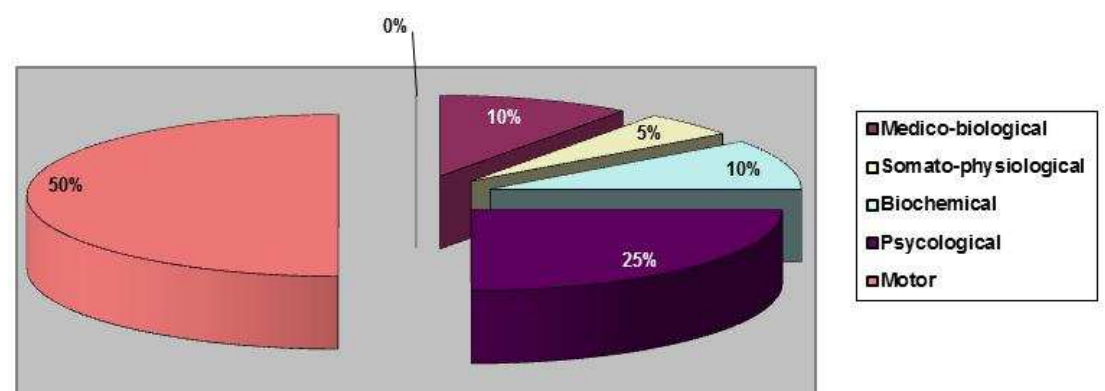

Figure 2. Graphical representation of the responses to question Q2

Q3. What ways of improving early selection in football do you recommend?
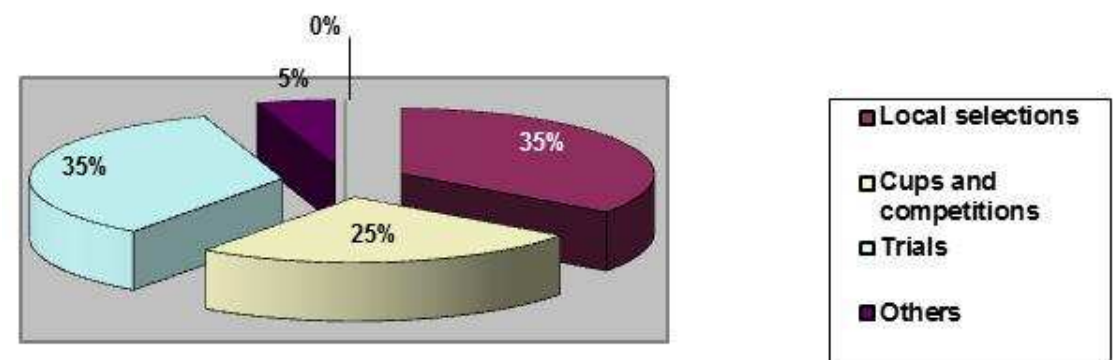

Figure 3. Graphical representation of the responses to question Q3

To this question the answers are equal, which shows that experts' opinions vary, that the categories listed are to take into account in order to improve the early selection process in the game of football. There is no favorite category, $35 \%$ of respondents were in favor of organizing regional selections and trials in schools and $25 \%$ favor cups and competitions.

Q4. Assess which of the following elements you consider important for the success of the selection process in children 6-8 years of age?
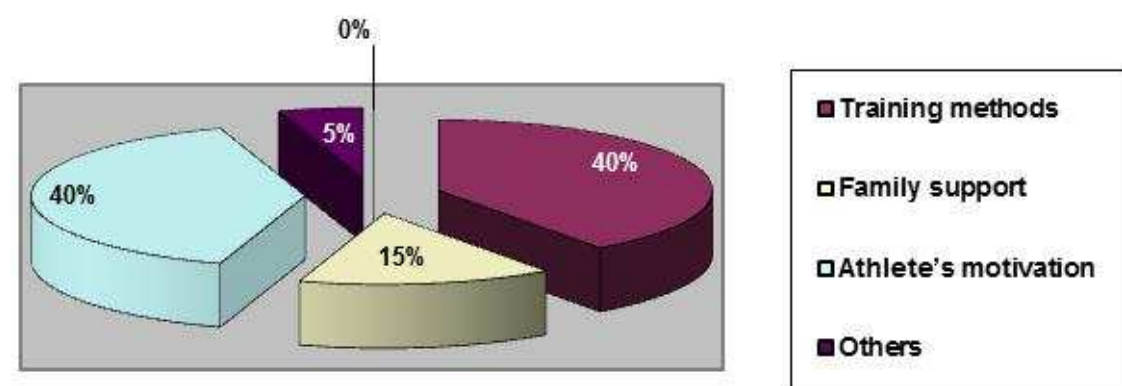

Figure 4. Graphical representation of the responses to question Q4

This question received from experts has equal answers (40\%) for the two elements considered vital in achieving remarkable results in the beginning of the selection process and throughout it, namely training methods and athlete motivation. Family support is also important, especially in this age where the child has not yet undergone individualization, but $15 \%$ is quite far from the first category.

Q5. Which of the following items do you think decisively influences athletes participation in programs organized by the club / school where you teach? 

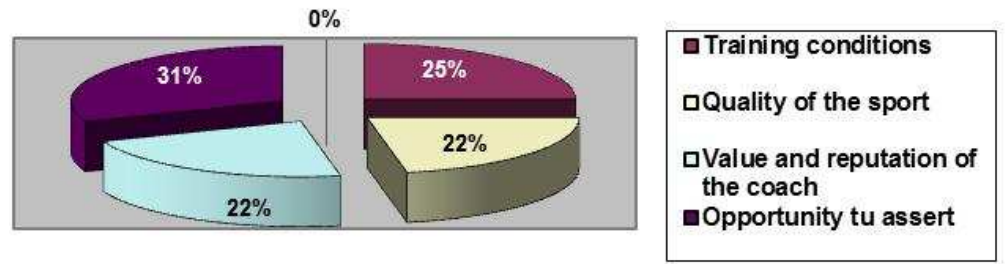

Figure 5. Graphical representation of the responses to question Q5

Also due to the age at which we relate during the investigation, it appears that the most appreciated as a criterion in choosing the club / school to practice a sport is the opportunity to assert (31\%), followed by the others listed in proportions almost identical: the training conditions (25\%), the quality of the sport and the value and reputation of the coach $(22 \%)$. At this age all children are convinced that if they are part of a club or school with a reputation in professional sports, it certainly will get them at least in the national selections.

\section{Conclusions}

After studying data from the survey, considering the graphic representations of results obtained on the sample of 100 respondents, we can draw a number of conclusions regarding the specific of initial selection in football in children 6-8 years of age.

Most respondents believe that the selection process sports games in general and particularly for the football game is a pretty good process performed in clubs / schools in Romania. However, there are many things that can be improved here including:

- Increasing interest of local authorities (AJF) in promoting sports competitions organized at the lowest age;

- Organizing with their support many selections like trials in schools, inter-schools cups, local tournaments in order to bring as many school age children of 6-8 years of age to the attention of specialists;

- Family involvement in maintaining children's interest in sports activities and using every opportunity to motivate athletes: awards in competitions, positive comments etc.

- Maintaining increased interest of coaches/ teachers in the development of motor skills in children 6-8 years of age in order to obtain good results in the selection process and at all stages of training.

\section{References}

1. Nicu A. (1993) Selection in sport - Criteria, samples andcontrol rules for the selection and training of children and juniors for high performance in sport, Bucharest, no. 805, p.43

2. Niculescu M., Vladu L. (2009) Sports Performance, Universitaria Publishing House, Craiova, p.18-20

3. Ionescu I.V., Demian M. (2007) Success in Soccer, ARTPRESS Publishing, Timişoara, p.162

4. Ionescu I.V., Demian M. (2007) Success in Soccer, ARTPRESS Publishing, Timişoara p. 187. 